\title{
Mravnost' ako atribút utvárania duchovnosti v tvorbe Jozefa Gregora Tajovského (na príklade poviedky „Hlucháň“, 1919)
}

\section{Lívia Barnišinová}

\author{
BARNIŠINOVÁ, L.: Morality as an Attribute of Forming Spirituality in \\ the Works of Jozef Gregor Tajovský (Exemplified by the Short Story \\ "The Muffled“, 1919)
}

SLOVENSKÁ LITERATÚRA 68, 2021, No. 1, p. 53-62

DOI: https://doi.org/10.31577/slovlit.2021.68.1.4

ORCID ID: https://orcid.org/0000-0001-6162-7374

Key words: 20th century Slovak

literature, Jozef Gregor Tajovský,

spirituality, literary character

The paper analyzes presence of spirituality in a so-called legionary short story by Jozef Gregor Tajovský (1874-1940) "Hlucháň" /"The Muffled" from the collection of proses $\mathrm{Na}$ vojne (At War, 1919). The interpretation is based on the thoerem that Marcela Mikulová formulated about the main character as a modern-day saint and Ivica Hajdučeková's thesis about the prayer as a „spiritualem“ reaching as far as the implicit level of the literary text and labelling the main character with the attribute ,apostolizing“. Using „vertical“ characteristics, Tajovský depicted the central character of the short story as a spiritually strong person, for whom belief in God is an essential attribute of living, thinking and doing. As religiosity and spirituality were in harmony in his life, being religious became the fundamental categorical imperative. Dynamics of love and courage to spread the word of God shifted him from the periphery to the centre of the situation, which made him an example to follow. In line with this, he developed the attributes of the apostole prototype, who was due to his personal dialogue with God elevated to the character of „homo religiosus“. Tajovský used the contrastive principle of the high and low as an active ingredient, which affected the inner level of the text. The outcome was a paradox which became the writer's tool for penetrating deeper into the inner worlds of the characters.

Klúčové slová: slovenská literatúra 20. storočia, Jozef Gregor Tajovský, spiritualita, duchovnost', literárna postava 

korpuse prozaického diela Jozefa Gregora Tajovského (1874-1940), dnes kanonického autora slovenskej literatúry (napriek starším ideologickým pochybnostiam o smerovaní časti jeho tvorby), ${ }^{1}$ prevažujú krátke žánre, ktoré zodpovedajú autorovmu sústredeniu sa na vnútorný svet postáv v drobnom epickom výseku ich života. Daný moment sa odrazil aj na Tajovského spôsobe utvárania postáv: na to, aby boli funkčné, nepotrebujú rozsiahly priestor. Vidno to i na poviedke „Hlucháń" - texte patriacom do osobitnej tematickej oblasti v Tajovského diele, ktorú tvoria tzv. legionárske poviedky, spracúvajúce námety z prvej svetovej vojny, ked' bol Tajovský príslušníkom československých légií v Rusku.

Čast' z literárnych textov, ktoré napísal počas vojny, vyšla v roku 1920 pod názvom Rozprávkyz Ruska. Tieto prózy boli neskôr zaradené do šest́zväzkového vydania jeho Diela (1953-1958), no nie všetky, pretože niektoré boli v danom čase vnímané ako ideologicky chybné. ${ }^{2}$

Autori legionárskej literatúry sa s fenoménom vojny vyrovnávali individuálne a umelecky rôznorodo. ${ }^{3}$ Vo viacerých textoch v zbierke Rozprávkyz Ruska je prítomný pátos a „existenciálna hrana“, na ktorú Tajovský zasadzuje literárne postavy vyrovnávajúce sa s krutým a brutálnym prostredím vojny a s pôsobením vojnovej mašinérie. Jeho literárne postavy sú však schopné nájst' si aj v takýchto nehumánnych podmienkach spôsob, ako si zachovat'ludskost'-východiskom sa pre ne stáva transcendencia. Ako píše Marcela Mikulová, „,v mimoriadnej situácii Tajovský spontánne obracia svoj zrak do transcendentna“ (Mikulová 2005: 149). Túto tendenciu možno identifikovat' napr. v prózach Janko Vrábel', „Hlucháň“, Pod jedličkou či Náš Ježiško, kde sa zvýšená subjektivita výpovede spája so zosilnenou religiozitou výrazu.

Poviedku „Hlucháñ “napísal Tajovský v roku 1916, knižne vyšla prvý raz v roku 1919 v zbierke Na vojne, pod pseudonymom M. Žiarsky (zbierku zostavil Janko Sršeň a vydala ju Slovenská liga v Amerike). Kým staršie literárnohistorické hodnotenia ju označovali za majstrovské dielo reflektujúce odpor k vojne (Rosenbaum 1956: 1152), aktuálne interpretačné čítania v nej identifikujú doposial' nepovšimnuté vrstvy. M. Mikulová poukazuje v súvislosti s ňou na znaky legendy, pričom hlavnú postavu vidí v pozícii novodobého svätca (Mikulová 2005:147), a aj na inom mieste píše o osudoch Tajovského hlavných postáv ako o hagiografiách tých najbiednejších (Mikulová 2010:76). Prítomnost' posvätnosti a duchovna anticipuje tiež Ivica Hajdučeková, ked'v tejto krátkej Tajovského próze upozorňuje na prítomnost' modlitby, ktorá „bola prostriedkom i nástrojom na obnovu l'udskosti“ (Hajdučeková 2016: 149). Navyše, hlavnú postavu označuje prívlastkom

1 Prvé komplexné literárnohistorické spracovanie prozaického diela J. G. Tajovského vyšlo až v roku 2005, ked' M. Mikulová vydala ako výsledok svojho dlhoročného výskumu monografiu Tajovského obrodenecká moderna (Mikulová 2005). Tajovského autorský portrét doplnila následne aj v knihe Paradoxy realizmu (Mikulová 2010).

2 Na margo edičných poznámok Karla Rosenbauma, editora šest́zväzkového Diela (1953 - 1958), M. Mikulová píše, že Tajovského realizmus vyhovoval „ideologicky exponovaným literárnym historikom“, avšak, „ked'jeho, privel'mi pravdivé črty odhal'ovali to, čo sa ideologicky ,nehodilo', inkriminované prózy (napríklad V dvoch úlohách, Florián Gajdoš, Čeljabinsk, Generál dr. Milan Štefánik, Za generálom Milanom Štefánikom, Na hroboch) jednoducho neboli zaradené do Diela“ (Mikulová 2005: 143).

3 Legionársku literatúru označuje Lenka Szentesiová ako subžánrovú jednotku spadajúcu pod okruh vojenskej literatúry (Szentesiová 2014: 98). 
"apoštolujúca“ (Hajdučeková 2016:149). Pri výskume duchovnosti pritom použiva hierarchizovaný pojmový aparát, ktorý umožňuje sledovat' duchovné tvarovanie postavy („homo religiosus“, „homo spiritualis“a „homo spiritus“, tiež religiozita, spiritualita, spiritualéma; Hajdučeková 2016: 140-162).

Titul poviedky „Hlucháñ“ môže mat' anticipačnú funkciu a môže čitatel'ovi naznačit' motivovanost' literárneho textu, teda jeho d'alšie ladenie. Metaforicko-protagonistický titul (Všetička 1992: 44) „Hlucháň“označuje hlavnú postavu deja. Zo štylistického hl'adiska sú v názve príznačné úvodzovky, ktoré sa vyznačujú nielen vyčleňovacou funkciou, ale aj funkciou ironizácie (Mistrík 1997: 242). Nepriamym pomenovaním tak dochádza k posunu významu a titul môže mat' kladný alebo pejoratívny, a teda ironický význam. Jeho prvý plán odhalí čitatel'už v úvodnej časti, kde je v krátkosti predstavená hlavná postava, Juro Kotliak - hluchý vojak, ktorého vojaci na základe jeho deficitu hanlivo prezývajú Hlucháň. Aj napriek hendikepu ho doktori poslali na vojnu, a tak musí Juro po večeroch stát' na stráži alebo v zákopoch.

Tajovský využíva prvky konštrukčného minimalizmu, ${ }^{4}$ aby predstavil krátke úseky (fragmenty) zo života hlavnej postavy. Autorský rozprávač tak predostiera čitatelovi základnú predstavu: Juro Kotliak je gazdovský sluha z oravskej dediny, ženatý muž, otec detí. Hlavná postava je zobrazená v sociálnych väzbách a v priestore dediny, aby sa v d'alšom sujetovom pláne rozvinula. Následne sa čitatel' dozvedá o okolnostiach Kotliakovho odchodu na vojnu.

Juro spočiatku nevie, čo je vojna. Pozná ju len z počutia, lebo „aj v kostole sa modlievajú: ,Od hladu, moru a vojny - vyslobod'nás Pane!'“ (Tajovský 1919: 3). Paradoxne, aj Kotliakova žena je „vd’ačná bohu“, že má hluchého a starého muža, dúfa, že vojna sa ich nedotkne a jej muž nebude odvedený. Napriek tomu prichádza Kotliakovi povolávací rozkaz a musí narukovat'. V komentári rozprávača badat' výraz bezmocnosti s podtónom irónie, ked' poukazuje na nezmyselnost' jeho odvodu, pretože „už príde, vari, rad i na Peja, starého, slepého koňa, ked' Jura vzali..." (Tajovský1919: 4). Nepriame prirovnanie hlavnej postavy k zvieratu naznačuje jej nízku hodnotu, čo text posúva do tenznej roviny a vytvára napätie. Ukotvenie hlavnej postavy v sakrálnom priestore (v kostole) evokuje sakrálny rozmer priestoru a je zároveň predzvest'ou duchovne ladeného rázu poviedky.

Hendikep hlavnej postavy je na vojne spočiatku vnímaný ako isté „simulantstvo“, ba dokonca ostatní vojaci si myslia, že Juro klame: „Juro narukoval. Nepočul. Doktor naložil ho pozorovat'. Jurovi sa otvorili uši, dostal simulant po ústach a marš do kasárne. Zase mu zal'ahlo, ohluchol. Pozorovali ho znova, a Juro, švindler “ zase dostal a vrátili ho do kasárne ako zdravého, súceho" (Tajovský 1919:5). Ústredná postava je preto sociálne zaradená k ostatným „zaostalým“: „Oficieri povyberali podobných nahluchlých, nasprostastých, poloslepých, t'arbavých a podobných a dali im čestné meno, extra cúgu“" (Tajovský 1919: 6).V texte tiež badat' náznak intuitívneho pacifizmu, a to v situácii, ked'Jurovi miesto dreveného „drúčku“ dajú pušku. Vidí v nej živú bytost', ktorú musí kŕmit' „žrádlom“ a ktorú by najradšej hodil do vody (Tajovský 1919: 29).

4 Oskár Čepan o konštrukčnom minimalizme u Tajovského píše: „Autor obvykle zobrazuje jednu výraznú postavu v jedinej životnej situácii, výnimočne v 2 - 3 , doplnkových okolnostiach““(Čepan 2001: 201). 
Práve Kotliakov pacifistický prístup k vojne je v nasledujúcej časti poviedky reflektovaný vel'mi intenzívne, hoci na malej ploche. Ak Oskár Čepan písal o Tajovského rozprávačovi ako o tom, ktorého „komentáre dodávajú autentickej reči postáv príznaky významovej úplnosti“ (Čepan 2001: 199), v poviedke „Hluchán “ to platí dvojnásobne. V momente, ked' sa rozprávač zmení z autorského rozprávača na „svedka“ situácie (Čepan 2001:199), autor presúva význam príbehu z povrchovej roviny textu na jej vnútornú úroveň, na ktorej sa hlavná postava postupne formuje, utvára sa dejom. ${ }^{5}$ Tajovský tak prostredníctvom náznakov nepriamej charakteristiky implicitne realizuje vnútornú charakteristiku postavy.

Rozprávač „nezavádza“ čitatel'a, nezahal'uje zobrazované udalosti, ale $\mathrm{v}$ priebehu deja postupne poodhaluje ich skrytý zmysel. Preto priamo anticipuje smrt' hlavného hrdinu už v úvode poviedky, čím naznačuje, že ide vlastne o postmortálny príbeh: „Nedlho vojenčil Juro. Ale ja a všetci, čo sme s ním žili, máme peknú spomienku nañ “ (Tajovský 1919: 6). Na základe toho je potom možné usudzovat', že ide o prvok legendy. Prístup vojakov k Jurovi Kotliakovi však nie je spočiatku taký prívetivý, ako by sa z týchto slov mohlo zdat'. Z polohluchého vojaka si ostatní robia žarty, vysmievajú sa mu: „,Ved'mu kanóny uši otvoria', - usmial sa kadet a začali sa vtipy, ktoré bol'avý smiech vyvolali nám nejednému“ (Tajovský 1919: 7). Juro nerozumie po mad'arsky, nevie, že si z neho ostatní robia posmech, vo svojej nevedomosti sa prispôsobuje správaniu ostatných: „kývol hlavou a podozrieva, čo by to malo znamenat', za ostatnými smrštil tvár do úsmevu ako ked'sa druhísmejú a ty by si sa tiež chcel a nevieš, na čom" (Tajovský 1919: 7).

Juro na vojne nevyčnieva z radu, ba naopak, je plachý, „uhýba sa každému [...], stáahujúc sa do klbka, ako slimáčik“" (Tajovský 1919: 8), a ked' druhí vojaci chcú, aby si l'ahol na miesto, kde pluli, nebúri sa, ale poníži sa, lebo sa necíti byt' s nimi rovný. Naznačený pohyb fyzického schúlenia sa môže tiež znamenat' vnútornú dištanciu hlavného hrdinu od kolektívu, nestotožnenie sa s jeho hodnotami, uzatváranie sa do vlastného vnútra. Hlavná postava tak uniká, dostáva sa na perifériu.

Od istej chvíle však čitatel'a v texte už neupútava Jurova „hluchota“, akási zaostalost' či „nasprostastost'“. Rozprávač odvracia pozornost' od hendikepu hlavnej postavy, aby sa sústredil na jej implicitne reflektovanú vnútornú charakteristiku, ktorá je v príkrom kontraste k ostatným postavám. Príznačnou situáciou je rozdel'ovanie zemiakov v zeml'anke, ked'si Juro neberie zemiaky z pahreby tak ako iní, ale nesmelo sa prihovára ostatným vojakom: „I ja by jeden-dva... A keby bolo ako doma -štipka bryndze a za skleničku... - nedopovedal. - Chod'te si nadriapat! - neprajne zreval - či bol zemiak? - a vychytil ho od uhlia a kobril'al v rukách, umäkušil i rozpučil. - Ale daj mu jedon... - Daj svoj!“ (Tajovský 1919: 9). Takáto eskalácia situácie nesie so sebou prvky naturalizmu premietnuté do drsného správania vojakov, pudovosti, živočíšnosti, ale aj do samotného determinizmu plynúceho z vojnového prostredia.

Ani v situácii, ktorá demonštruje hranicu, za ktorú je človek ochotný zájst', sa však Juro nebúri proti krivdám, neháda sa. Hlavná postava na odstrkovanie a degradáciu odpovedá nečakane: Juro Kotliak sa modlí. V tejto krízovej situácii má odvahu a potrebu zhovárat' sa s Bohom prostredníctvom modlitby, najmä na

5 O epickej postave v tvorbe J. G. Tajovského, ktorá môže byt' deduktívna, apriórna (dej je produktom postavy), resp. induktívna, aposteriórna (postava sa utvára dejom), bližšie Miko 1974: 71-80. 
fronte, medzi ostatným chlapmi, a to aj za cenu odsúdenia či prehĺbenia spoločenskej degradácie. Svojím konaním môže vzbudit' u druhých ešte väčší výsmech, čím sa ešte viac vyčlení z kruhu vojakov. „Hlucháňova“ modlitba vyznieva oproti pudovému správaniu ostatných mužov ako paradox. ${ }^{6}$ Dochádza k uplatneniu kontrastného princípu (Všetička 2017: 167) v prepojení „vysokého“ a „nízkeho“.7 Hoci sa modlí potichu, jeho modlitba zasiahne ostatných takým silným spôsobom, ktorý u človeka nastáva len vo výnimočnej, v hraničnej situácii:

„Jurovi bolo to iste šeptané, ostatným hlasné predmodlievanie. Ale jaké? Jaká prenikavá, úprimná modlitba. V úzkostiach smrti modlil si sa v duchu neraz, srdce zamieralo, studený pot stekal čelom, ale taký dojem z modlitby mal som ešte iba raz v živote: ked'strýc, čo pri pamäti zomieral, modlil za naším kostolníkom modlitbu za umierajúcich... Juro ako by razom pochopil, kde je, vakom nebezpečenstve života, modlil sa a my načúvali... akoby sme sa nikdy nikto neboli modlili“ (Tajovský 1919: 9-10).

Modlitba hlavnej postavy zásadne zmení uvažovanie a d'alšie prežívanie vojakov. V tejto príznačnej situácii sa čitatel'ovi potvrdzuje krestáanský rozmer hlavnej postavy, ktorá nevyznáva Boha len v inštitucionalizovanej podobe (v priestore kostola), ale s Bohom žije v neustálom dialógu, je s ním bytostne prepojená, preto sa škála duchovnosti zároveň dopíňa o spirituálny rozmer, ktorým Juro Kotliak disponuje. Jeho úpenlivá modlitba vojakov „preobráti“8 a obnoví v nich ludskost' (Hajdučeková 2016:149), ktorá je vzhl'adom na okolnosti potlačená. ${ }^{9}$ Výsledkom vplyvu modlitby na vojakov je obrat v sujete - Jurovi zrazu núkajú zemiaky. Spirituálny zážitok Kotliakovej modlitby stimuloval ich etický postoj a správanie. Hlavná postava však preukazuje svoju silnú náboženskú zásadovost' a podriadenost'Bohu vo všetkom, dokonca aj v kritickej životnej situácii, a to formou odriekania (Juro odmietne zemiak, lebo sa „už prežehnal“ na záver dňa).

Hoci Jurova vojenská degradácia pokračovala (najprv ho postavili na stráž pred zákopy, potom $\mathrm{k}$ drôtom, neskôr za zákopy, kde sa naučil driemat' postojačky ako „hoviadko“), nebol už „hlupákom“, ktorý sa bezdôvodne smeje na vtipoch ostatných. Ked'ho nakoniec nebrali ani na pol'nú stráž, ale nechali ho starat' sa o zemlanku, svoju „službu“ zobral vážne. Neostal v úzadí. Nachádza ,výhody“vo svojom hendikepe a usiluje sa byt' osožný ostatným. Stará sa o vojakov, varí, perie, stráži oheň - stáva sa ich „gazdinou“. Vojaci preňho už neznamenajú

6 O paradoxe píše napr. Michal Harpáň: „Paradox má teda charakter aforistickej myšlienky, jeho protirečenie je len zdanlivé, slúžiace na vyslovenie hlbšej myšlienky, v ktorej sa prejavuje životná pravda a skúsenost"“ (Harpáň 2004: 109).

7 Na prepojenie a zmenu pohl'adu na ,vysoké“ a ,nízke“ v období realizmu upozorňuje aj M. Mikulová: „Práve v období, o ktorom píšeme, dochádza k zásadnému zlomu v hodnotení ,vysokého“ a ,nízkeho“ v literatúre - ide o zmenu axiologického pohl'adu: to, čo sa považovalo za vysoké, bolo zrelativizované a nahradené ,nízkym، (žánrovo, jazykovo, tematicky atd.)“ (Mikulová 2005: 62).

8 Pavel Říčan definuje ,preobrátenie“ predovšetkým ako „obrácení ve smyslu vnitřní změny spočívající v uvěření, přičemž víra má ovšem řadu forem“ (Říčan 2007: 266). Klasifikuje tiež preobrátenie na také, pre ktoré sa človek rozhodne, alebo také, ktoré nadobudne znovuzrodením (nutnost' „krstom Ducha“) (Říčan 2007: 266).

9 Tomáš Halík vníma náboženskost' ako prirodzenú dimenziu človeka: „Náboženskost pokládám za přrirozenou dimenzi člověka a společnosti [...] Může být rozvinuta a pěstována [...], aneb zůstávat na okraji života, zastíněna něčím jiným, nebo být úplně zanedbána, či dokonce vědome potlačena“ (Halík 2004: 28). 
58 hrozbu v podobe jednej hviezdičky na uniforme, zrazu sú preňho „tí, jemu rovni“, ktorí mu rozumejú, pochvália ho: „Takých som vám, oravských! vítal natešený kamarátov, predkladajúc posolené, sypkézemiaky, čo označoval slovom,oravských", a tešil sa pochvalám ako dobrá kuchárka" (Tajovský 1919: 9-10). Hlavná postava sa pomaly presúva z periférie do pomyselného centra. Tým dochádza v konfigurácii postáv k zásadnej zmene.

Prehlbovanie väzieb s vojakmi podnecuje Jura k odkrývaniu jeho bezprostredného vzt'ahu k Bohu. Nielenže sa modlí, na čo si už vojaci „boli privykli“, ale „po čase, ked'bol sám v zemlianke, osmelil sa i zaspievat'. Spieval, aké mu na um prišli, ale najviac adventné, pôstne" (Tajovský 1919: 13). Náboženskými piesňami i modlitbami nielen lámal medziludské bariéry, no vojakom pripomínal ludskost' a potrebu (vonkajšími okolnostami potlačeného) hlbšieho duchovného rozmeru ich existencie. Modlitby a duchovné piesne sa stávajú spojivom postáv-zjednocujúcou spiritualémou, ${ }^{10}$ ktorá vo vojakoch revitalizuje ludskost'.

Juro vystupuje v tejto fáze deja aj ako svorníková postava (V̌̌etička 1992: 25), stmeluje kolektív vojakov, implicitne im „káže“ o dobrých mravoch, o slušnom správaní, je ich „svedomím“:

„,Kde si môj premilý Ježiši Kriste? V úzkostiach a biedach sám pri mne stoj, sám pri mne stoj!‘ Tú nám každý večer vyňal všetkým z duše a my niektorí, neznajúc sním spievat', začínali sme za ním plakat'... Ked'sme sa vše hádali, vadili, Juro, neberúc $v$ škriepkach účast', z čista, jasna začal spievat'a užsa niekto našiel, čo povedal: ,Nevad'te sa, počúvajte." Tak miernil nás v hneve, naprával naše city" (Tajovský 1919:14).

V správaní hlavnej postavy badat' známky asketického správania - Juro radšej obetoval zo svojho pohodlia iným, nejedol, nebral si zemiaky, len ked' mu podali, a vojaci ho „radi mali ako otca“. Juro Kotliak sa z pozície outsidera dostáva na úroveň opatrovníka - v role gazdinej, o vojakov sa stará priam ako matka o svoje deti. Rodovo korektne je potom na úrovni ich otca, t. j. stala sa z neho uznávaná mužská autorita. ${ }^{11}$ Takýmto spôsobom sa hlavná postava dostáva z periférie do

10 Autorom pojmu je Ján Sabol, ktorý ho definuje nasledovne: „Medzi formou a obsahom slova sa vytvára vnútorná magnetická sila, ktorá môže prenikat' lexikálno-sémantickým priestorom tejto jednoty a dodávat' mu konotatívnu energiu vyššieho, transcendentálneho posolstva. A tak vznikol termín spiritualéma na pomenovanie lingvisticko-semiotickej jednotky označujúcej duchovnost', spiritualitu“" (Sabol - Sabolová - Sersenová 2010: 92).

11 Podobne je tvarovaná aj hlavná postava novely Štefana Letza Nahý vojak zo zbierky Obyvatelia dvora (1927). Letzov Tobiáš má s Jurajom Kotliakom niekol'ko spoločných čŕt a Letzova próza je takisto zasadená do tvrdého a neludského prostredia vojny. Retrospektívna narácia kapitána Vadoviča odhaluje Tobiáša ako „svätca“ zákopov (Letz 1927: 181), ktorý bol starý, no snažil sa nezaostávat' medzi ostatnými a vo svojej starobe našiel výhody - staral sa o ostatných vojakov ako ich otec, obnovoval v nich ludskost' a modlil sa dňom a nocou, aby kríž v poli, ktorý pre ostatných predstavoval nádej, vydržal d'alšie prestrelky. Rozdiel $\mathrm{v}$ duchovnom preživaní týchto dvoch postáv je $\mathrm{v}$ šírení viery - Tobiáša za prototyp apoštola nemožno označit. Život hlavnej postavy sa končí symbolicky, pri pokuse opravit' kríž. Smrt' tohto nahého vojaka, ktorý sa vyzliekol pred Kristom visiacim na krízi, vyznieva symbolicky ako protest proti vojne, uniforme a násiliu. Na religiózne motívy v tejto novele upozornila už Dagmar Kročanová, ktorá jej záver - Tobiášovu smrt'- označuje za obetu a pripodobňuje ju „Kristovmu údelu na Golgote“ (Kročanová 2014: 72). 
centra, čo zodpovedá princípu centrácie, jednému zo základných princípov duchovného rozmeru literárnej skutočnosti. ${ }^{12}$

Jurovo kázanie a starostlivost' o jedenástich vojakov posilňuje úvahy o alúzii na Kristových nasledovníkov - dvanástich apoštolov, ${ }^{13}$ medzi ktorými nadobúda Juro osobité kristocentrické postavenie šíritela viery - apoštola. ${ }^{14}$ Vo vztahu k iným pripomína postavu, ktorá sa vyznačuje tým, že prevyšuje ostatných v oddanosti Bohu, príkladnou a obetavou službou bližnemu (je pre nich gazdinou), bezchybnou mravnost'ou (implicitné kázanie o dobrých mravoch) a asketickým spôsobom života (odrieka si jedlo, zostáva spat' pri chladných dverách a pod.).

Smrt' hlavnej postavy rozprávač nerozvádza ani nemonumentalizuje. V mortálnom finále ${ }^{15}$ stroho konštatuje: „Večer vyšiel za zákopy na svoju obyčajnú ,službu', a ráno ho našli mŕtveho“ (Tajovský 1919: 16). Dôležité je zvýraznit' čosi iné - duchovný odkaz, ktorý po sebe hlavná postava zanechala: „Juro nechal nám na pamiatku pieseň: ,V úzkostiach a biedach sám pri mne stoj, sám pri mne stoj' a tú sme si potom v̌̌e večer tiško zaspievali a, ako ktorý, odvracali hlavy a utierali slzy..." (Tajovský 1919: 17). Na to, že Juro Kotliak už ako postmortálna postava (Všetička 1992: 26) ešte stále vplýva na svedomie vojakov, že ich robí ludskejšími, lepšími, poukazuje okrem predchádzajúceho úryvku tiež fakt, že mu vojaci dali postavit' kríž. Metamorfným motívom ${ }^{\mathbf{1 6}}$ „preobrátenia“ vojakov autor zvýraznil uznanie hodnoty duchovnosti a religiozity, úcty v ich konaní. Pretvára vojakov z predstavitel'ov „nízkych“ hodnôt na tých, ktorých modlitba/spiritualita povznesie na úroveň „vysokého“. ${ }^{17}$ Naopak, „Hlucháňa“ povýšil autor prostredníctvom „,vertikálnej" charakteristiky ${ }^{18}$ na postavu, v ktorej je možné identifikovat duchovne založenú bytost's pevným životným postojom, ktorá sa pre druhých stáva vzorom.

Spätne sa ukazuje, že Tajovský poskytuje čitatel'ovi možnost' vol'by pri prehodnotení sémantiky názvu poviedky „Hlucháñ“. Do úvahy pripadajú dve interpretačné roviny titulu: prvým významom je expresívnost'v pomenovaní nepočujúceho človeka, v druhom významovom pláne pomenovanie môže znamenat' posun od ironického k obraznému významu. Juro bol síce hluchý voči „kanónom“ (ktoré vystupujú ako synekdocha vojny), ale vd'aka viere dokázal načúvat' človeku. V druhom významovom pláne sa tak otvára priestor pre eticko-morálny a jeho prostredníctvom aj duchovný rozmer v tvarovaní postavy.

Hlavná postava poviedky je osobitá svojím duchovným tvarovaním. Tajovský ju zasadzuje do prostredia vojny, kde sa jej postoj k základným hodnotovým

12 Princíp centrácie označuje I. Hajdučeková ako jeden z príznakov, na základe ktorého môžeme skúmat' rozvinutie duchovna v kompozičnej štruktúre (Hajdučeková 2016: 166).

13 Číslo dvanást' má v Biblii aj v krestanstve významnú úlohu, predstavuje symbol dokonalosti a úplnosti (Becker 2007: 60).

14 Apoštol-posol, ohlasujúci evanjelium, z gr. aposteló, posielat' (Vargaš 2006: 37). Apoštol je zároveň aj súčastou apoštolskej tradície, ktorej ciel'om je odovzdávanie Kristovho posolstva, ktoré sa od začiatku krestanstva uskutočňovalo kázaním, svedectvom, ustanovizňami, kultom a inšpirovanými knihami (Ďurica 2005: 61).

15 F. Všetička vymedzuje termín vo finále, ak je literárne dielo ukončené smrtou (Všetička 2017: 169).

16 Princíp tohto motívu zachytáva vývinovú premenu, ktorá sa od vstupného variantu završuje v jeho záverečnej forme, ak vstupný a záverečný variant sú zvyčajne diametrálne odlišné (Všetička 2017: 168). 17 Na podobný princíp premeny pomocou poetickej figúry chiazmu upozornila M. Mikulová v interpretácii poviedky Maco Mlieč (Mikulová 2005: 124).

18 Termín prevzatý od J. Gbúra (Gbúr 2014: 17-27). 
otázkam nemení, neprispôsobuje sa situácii. Juro Kotliak sa počas deja presúva z periférneho postavenia do centra situácie nie preto, aby sa stal dobrým vojakom, ale človekom. Vyznačuje sa l'udskostou plynúcou z viery v Boha, ktorá sa prejavuje zbožnostou v modlitbách a piesňach. Spájajúcim elementom v konfigurácii postáv sa stala spiritualéma, ktorá ich prostredníctvom ústrednej postavy kristocentricky ukotvila. Vd'aka svojmu nemennému náboženskému presvedčeniu sa intuitívny pacifizmus hlavnej postavy postupne zmenil na uvedomelé odmietanie vojny.

Tajovský využíva kontrastný princíp vysokého a nízkeho ako aktívnu zložku, ktorá zasahuje do vnútornej roviny textu, a tak zvyšuje jeho umelecký účinok. Vysoké (morálne a duchovné hodnoty hlavnej postavy) a nízke (neludské prostredie vojny, bezcitné správanie vojakov) sa v tomto prípade stávajú kontrastom, ktorý sa vyhrotí až do paradoxu - Tajovský prostredníctvom „vertikálnej“ charakteristiky povýšil zaznávanú postavu „Hlucháňa“ nad ostatné a tá sa pre všetkých stala vzorom. Paradox je pre autora zároveň nástrojom, ktorým mohol nielen hlbšie nazriet' do myslenia, konania a prežívania postáv, ale takisto zásadne zmenit ich konfiguráciu v prospech zvýraznenia duchovného posolstva.

Takéto čítanie Tajovského textu ukazuje na prítomnost' náboženskej motivácie, teda potvrdzuje moment, ktorý staršia slovenská literárna história jednoznačne odmietala. ${ }^{19}$ Duchovnost' a spiritualita sú totiž pevne prítomné v tvarovaní hlavnej postavy. Neustály dialóg Jura Kotliaka s Bohom z neho robí postavu tvarovanú vintenciách „,homo religiosus“,20 ktorú môžeme vnímat prostredníctvom jej myslenia, založenom teocentricky a najmä kristocentricky. Viera je pre Kotliaka stredobodom života, v ktorom sa snaží praktizovat' náboženské idey. Jeho účinkovanie medzi vojakmi sa vyznačuje askézou, odriekaním a apoštolským elánom (Komorovský 1997: 19).

Ked'že teologické termíny pre označenie jednotlivca „svätý“ a „apoštol “ sa vyznačujú sémantickou otvorenostou, ich charakteristické atribúty majú difúznu povahu a v rôznych vlastnostiach sa navzájom prekrývajú (napr. hlásanie Božieho slova, morálka, obetavá služba iným, asketický spôsob života), no takisto sa odlišujú. Oproti apoštolovi je literárna postava svätca charakteristická najmä konaním zázraku počas života i bezprostredne po smrti, ${ }^{21}$ čo v poviedke „Hluchán̆“absentuje.

19 Napr. rusistka Soňa Lesňáková definovala Tajovského prístup v kontexte hladania jeho väzieb $\mathrm{k}$ L. N. Tolstému takto: „Niet uňho [...] tolstojovskej náboženskej motivácie. Tajovský nepíše a nevolá po nábožných cnostiach. Ide mu o morálku každodenného života, o podporovanie prirodzených dobrých vlastnosti““ (Lesňáková 1974: 104-105).

20 Pojem „homo religiosus“ použila vo svojom výskume I. Hajdučeková, odvolávajúc sa na religionistu Jána Komorovského: „,Homo religiosus‘ je viac ako tvor prirodzene nábožensky disponovaný, ktorého religiozita sa môže plne rozvinút', ale v prípade, že sa nepestuje, nezvel'aduje a nezošlachtuje, môže zakrniet'“ a d'alej pokračuje, ,človek sa stáva osobnost'ou typu ,homo religiosus' vtedy, ked' dospeje k poznaniu transcendentného Bytia a s touto skutočnost'ou nadviaže osobný kontakt, takže participuje na Božom živote, onticky je spätý s Bohom, koná pod zorným uhlom jeho prítomnosti“"(Hajdučeková 2016: 150-151). 21 Porovnaj napr. Brtáňová 2013: 22. 
Postava svätca ${ }^{22}$ má tradičné žánrové zaradenie - býva súčastou legendy, resp. životopisov svätých. ${ }^{23} \mathrm{~S}$ ohl'adom na to je možné prehodnotit žánrové kvality analyzovanej Tajovského poviedky, ktorá má síce isté prvky legendickosti, ale dôsledne nekorešponduje s vymedzením legendy. ${ }^{24}$ Tieto prvky môžeme v poviedke „Hlucháñ “ pozorovat'v konaní hlavnej postavy (napr. v tom, že pre ostatných predstavuje vzor krestanského života, prevyšuje iných v oddanosti Bohu, príkladne a obetavo im slúži, vyznačuje sa bezchybnou mravnost'ou, asketickým, a teda bohumilým spôsobom života ${ }^{25}$ a pod.), alebo aj uzatvoreným príbehom, ktorý je podaný ako postmortálny. Charakteristickou vlastnostou Jura Kotliaka je láska k Bohu a k bližnemu: pri láske k Bohu túži po jej spoluprežívaní, lásku k blížnemu vyjadruje otcovskou starostlivost'ou o druhých. Dynamika lásky, ako súčast' krestanskej spirituality, svedčí o tom, že hlavná postava má odvahu hlásat' Božie slovo s vedomím, že ju za to iní môžu prenasledovat' alebo ponižovat, ${ }^{26}$ čo $\mathrm{z}$ nej vytvára prototyp apoštola.

Štúdia je výstupom grantového projektu APVV-19-0244 Metodologicképostupyv literárnovednom výskume s presahom do mediálneho prostredia. Zodpovedný riešitel': prof. PhDr. Ján Gbúr, CSc. Doba riešenia: 2020 - 2024.

\section{Pramene}

LETZ, Štefan, 1927. Nahý vojak. In LETZ, Štefan. Obyvatelia dvora. Bratislava - Praha: Sväz slovenského študentstva. Nákladom Leopolda Mazáča v Prahe.

TAJOVSKÝ, Jozef Gregor, 1919. „Hlucháň.“ In TAJOVSKÝ, Jozef Gregor. Na vojne. Slovenská liga v Amerike.

\footnotetext{
Literatúra

BECKER, Udo, 2007. Slovník symboli̊. Praha: Portál.

BRTÁŇOVÁ, Erika, 2013. Na margo staršej literatúry. Bratislava: Kalligram.

BUBEN, Milan - KUKLA, Otakar Aleš-KUČERA, Rudolf, 1995. Svati spojuji národy: Portréty evropských světcu․ Praha: Panevropa.

ČEPAN, Oskár, 2001. Próza slovenského realizmu. Bratislava: Veda.

ĎURICA, Ján, 2005. Stručný katolícky teologický slovník. Trnava: Dobrá kniha.

FIORES, Stefano de - GOFFI, Tullo, 1999. Slovník spirituality. Praha: Karmelitánske nakladatelství.

GBÚR, Ján, 2014. „Vysoké“ a „nízke“v próze slovenského literárneho realizmu. In Estetické a axiologické pohl'ady na literatúru konca 19. a začiatku 20. storočia. Košice: Univerzita Pavla Jozefa Šafárika, s. 17-27.
}

22 Podla teologickej klasifikácie sú svätci tí, ktorí sú verejne uctievaní, pretože konali a milovali dobro, heroickým spôsobom svedčili o láske ku Kristovi, za prejav ich svätosti je považovaný predovšetkým zázrak alebo zázračný čin. Sú zbožní a horliví vo viere, majú bezchybnú mravnost', ničím nepoškvrnené cnosti, majú zásluhu na rozvoji cirkvi a šírení náboženstva a pod. (Buben - Kukla - Kučera 1995: 8).

23 Richard Marsina označuje legendy ako volné spracovania životov svätých, hovoriace o ich pôvode a živote, ako aj o zázrakoch vykonaných ich priamym zásahom alebo na príhovor. Autor chcel svätca ukázat' v čo najpriaznivejšom svetle (Marsina 1997: 15). Podla Eriky Brtáňovej sa legenda odvíja od klasického triadického členenia obsahu na život (vita), utrpenie (passio) a zázraky (miracula). Niekedy sa k týmto trom zložkám pričlení aj prenesenie svätcovho tela (translatio) (Brtáňová 2013: 20-22).

24 Na znaky legendy pri interpretácii Tajovského próz poukázala M. Mikulová (2005: 147).

25 Porovnaj Marsina 1997: 15.

26 Porovnaj Fiores-Goffi 1999: 39. 

Univerzita Pavla Jozefa Šafárika.

HALÍK, Tomáš, 2004. Vzýván i nevzýván. Praha: Nakladatelství Lidové noviny.

HARPÁŇ, Michal, 2004. Teória literatúry. Bratislava: Tigra.

KOMOROVSKÝ, Ján, 1997. Psychologický typ „homo religiosus“. In Duchovný rozmer osobnosti: Interdisciplinárny prístup. Bratislava: Ústav experimentálnej psychológie SAV, s. 15-21.

KROČANOVÁ, Dagmar, 2014. Tematizácia prvej svetovej vojny v krátkej próze medzivojnového obdobia. In Studia Academica Slovaca 43. Prednášky 50. letnej školy slovenského jazyka a kultúry. Bratislava: Univerzita Komenského, s. 69-92.

LESŇÁKOVÁ, Soňa, 1974. Jozef Gregor-Tajovský a ruská literatúra. In Jozef Gregor-Tajovsky - Janko Jesenský: zborníkz konferencie k 100. výročiu narodenia spisovatelov 3. - 4. mája 1974 $v$ Banskej Bystrici. Bratislava: Osvetový ústav, s. 103-113.

MARSINA, Richard, 1997. Legendy stredovekého Slovenska. Ideály stredovekého človeka očami cirkevných spisovatelov. Budmerice: RAK - Nitra: Mesto Nitra.

MIKO, František, 1974. Epická postava u Jozefa Gregora-Tajovského. In Jozef Gregor-Tajovský -Janko Jesenský: zborník z konferencie k 100. výročiu narodenia spisovatelov 3. - 4. mája 1974 $v$ Banskej Bystrici. Bratislava: Osvetový ústav, s. 71-80.

MIKULOVÁ, Marcela, 2005. Tajovského obrodenecká moderna. Bratislava: Kalligram.

MIKULOVÁ, Marcela, 2010. Paradoxy realizmu. Bratislava: Veda.

MISTRÍK, Jozef, 1997. Štylistika. Bratislava: Slovenské pedagogické nakladatel'stvo.

ROSENBAUM, Karol, 1956. Nad prózou Jozefa Gregora-Tajovského. In Jozef Gregor Tajovský v kritike a spomienkach. Sborník. Bratislava: Slovenské vydavatel'stvo krásnej literatúry, s. $1129-1157$

ŘÍČAN, Pavel, 2007. Psychologie náboženství a spirituality. Praha: Portál.

SABOL, Ján-SABOLOVÁ, Ol'ga-SERSENOVÁ, Juliana, 2010. Spiritualéma. Verbum: časopis pre krestáanskú kultúru, roč. 21, č. 1, s. 92-97.

SZENTESIOVÁ, Lenka, 2014. Dve podoby legionárskych spomienok (Janko Jesenský a Mikuláš Gacek). In Studia Academica Slovaca. 43. Prednášky 50. letnej školy slovenského jazyka a kultúry. Bratislava: Univerzita Komenského, s. 93-111.

VARGAŠ, Štefan a kol., 2006. Teologický a náboženský slovník I. diel A - K. Trnava: Spolok sv. Vojtecha.

VŠETIČKA, František, 1992. Stavba prózy. Olomouc: Vydavatelství Univerzity Palackého. VŠETIČKA, František, 2017. Slovesné sondy. Olomouc: $\mathrm{H}+\mathrm{H}$.

PaedDr. Lívia Barnišinová, PhD.

Filozofická fakulta UPJŠ

Šrobárova 2

04001 Košice

Slovenská republika

E-mail: livia.barnisinova@upjs.sk 